\title{
MATHEMATICAL MODEL OF TERRITORIAL DEVELOPMENT OF MARINE REGIONS BASED ON BIG DATA
}

\author{
Liu Chang \\ Ph.D., Associate Professor, Institute of electronics \\ and information engineering, Guangdong Ocean University, \\ (Zhanjiang City, Guangdong Province,PRC; e-mail: byndgjc@163.com) \\ Mamonov Kostiantyn \\ Doctor of Economics, Professor, \\ Professor of the Department of Land Administration \\ and Geological Information Systems O. M. Beketov National University of Urban Economy \\ (Ukraine, Kharkive-mail: kostia.mamonov2017@gmail.com
}

It was determined that in the system of territorial development of coastal areas at the present stage it is proposed to use mathematical tools and simulation that creates its information. The aim of the study is to determine directions of mathematical modeling of territorial development of coastal regions, given the characteristics of land relations. Objectives of the study are: the formation of the stages of mathematical simulation of territorial development of coastal regions, given the characteristics of land relations; construction of a mathematical model in the system of territorial development of coastal regions; the definition of criteria of adequacy of mathematical model in the system of territorial development, given the characteristics of land relations; interpretation of the results. Proposed and implemented the stages of mathematical simulation of territorial development of coastal regions, taking into account the trends and features of land use and change system of spatial, urban, investment, and environmental factors. The criteria of adequacy of mathematical models of territorial development of coastal regions. It forecasts changes in the system of spatial, urban, investment and environmental factors and changes in the index of territorial development, including coastal regions. A three-dimensional GIS model of condition monitoring and predictive trends of territorial development of land use, including coastal regions of Ukraine. For the sake of territorial development of coastal regions is suggested to use the experience of China. In particular, the form of the free economic zones, improving the efficiency of land use, the use of modern information systems spatial software, and the improved utilization of urban services, increase the level of investments on the basis of modern investment mechanisms.

Keyword: territorial development, coastal regions of Ukraine, coastal regions of China, spatial, urban, environmental, investment factors, land use, territorial development indicator, mathematical modeling, forecasting.

Formulation of the problem. Development processes in the state depend on the formation and implementation of territorial development of regions, the level and efficiency of land use. In modern conditions, territorial development depends on the influence of spatial, urban, investment and environmental factors. They create a comprehensive assessment system that determines the quantitative basis for informed decision making at the regional level. In the context of territorial development, coastal territories, where modern instruments of regional governance, such as free economic zones, are emerging, are of particular importance. This is evidenced by the experience of China, where the development of coastal territories is noticeable. At the same time, in the system of territorial development of coastal territories at the present stage it is proposed to use mathematical tools and modeling, which creates its information support. Therefore, the topic of research on mathematical modeling of territorial development of coastal territories is relevant and timely.

Analysis of recent research and publications. Theoretical and methodological provisions and approaches for providing elements of territorial development of regions are presented in the works of: T. Avramenko [1], O. Bakaeva [2], M. Grek [3], V. Kravtsiv [4], K. Mamonova [5-6], L. Sviridova [7], K. Stephen [8], V. Shipulin [9], P. Hendrick [10] and others.

Highlighting previously unresolved parts of a common problem. However, questions regarding the formation of systematic data regarding the territorial development of coastal regions through the use of mathematical modeling remain unresolved.

Setting objectives. The purpose of the study is to determine the directions of mathematical modeling of territorial development of coastal 
regions, taking into account the peculiarities of land relations. The objectives of the study are:

- formation of stages of mathematical modeling of territorial development of coastal regions, taking into account peculiarities of land relations;

- construction of a mathematical model in the system of territorial development of coastal regions;

- determination of the criteria of adequacy of the mathematical model in the system of territorial development, taking into account the peculiarities of land relations;

- interpretation of the results.

Materials and methods. Mathematical modeling of the territorial development of the coastal regions is developed by determining the criteria of adequacy of the mathematical models: Fisher F-test, Student's t-test, homo- and heteroskedasticity tests, residual autocorrelation and multicollinearity.

Outline of the main material. It is proposed to perform mathematical modeling of territorial development of coastal regions in the following stages:

- formation of information and analytical support for modeling the territorial development of coastal regions according to spatial, urban, investment and environmental factors;

- definition of systemic spatial, urban, investment and environmental factors;

- assessment of the integral indicator of territorial development of coastal regions, taking into account the directions and features of land use;

- determining the impact of systematic spatial, urban, investment and environmental factors on the integral indicator of territorial development of coastal regions, taking into account the directions and features of land use based on correlation and determination coefficients;

- development of mathematical models of the influence of spatial, urban, investment and environmental factors on the integrated indicator of territorial development;

- determination of the adequacy criteria of mathematical models: Fisher's F-test, Student's t-test, checks for homo and heteroscedasticity, for autocorrelation of residuals and multicollinearity;

- interpretation of the results.

On the basis of the information and analytical support developed, mathematical models of territorial development were developed and correlation and determination coefficients were determined (Table 1).

Based on the established links, the greatest influence of systemic environmental factors on the territorial development index of coastal regions is determined. Other systemic factors have little impact on the indicator of territorial development of coastal regions, taking into account the directions and features of land.

The adequacy criteria of the mathematical models testify to the reliability of the established relations, since the actual data of Fisher's F-test, Student's t-test exceed their normative values, check for homo or heteroscedasticity indicates homogeneity of data distribution, autocorrelation and correlation.

On the basis of mathematical modeling to ensure the territorial development of land use in the regions, it was found that it is radically necessary to change the trajectory of spatial

Table 1

Mathematical models of territorial development of coastal regions, taking into account directions and features of land use, rel. units

\begin{tabular}{|l|c|c|}
\hline \multicolumn{1}{|c|}{ Model name } & Mathematical model & $\begin{array}{c}\text { Correlation and determination } \\
\text { coefficients }\end{array}$ \\
\hline \hline $\begin{array}{l}\text { The influence of systemic spatial } \\
\text { factors on the indicator of territorial } \\
\text { development of coastal regions }\end{array}$ & $\mathrm{y}=-0,438 \times \mathrm{x}+2,957$ & $\mathrm{R}=0,14$ \\
\hline $\begin{array}{l}\text { Influence of systemic urban planning } \\
\text { factors on the indicator of territorial } \\
\text { development of coastal regions }\end{array}$ & $\mathrm{y}=-0,635 \times \mathrm{x}+4,44$ & $\mathrm{R}=0,33$ \\
\hline $\begin{array}{l}\text { Influence of systemic investment } \\
\text { factors on the indicator of territorial } \\
\text { development of coastal regions }\end{array}$ & $\mathrm{y}=0,038 \times \mathrm{x}+1,77$ & $\mathrm{R}^{2}=0,11$ \\
\hline $\begin{array}{l}\text { The influence of systemic environmental } \\
\text { factors on the indicator of territorial } \\
\text { development of coastal regions }\end{array}$ & $\mathrm{y}=0,041 \times \mathrm{x}+1,703$ & $\mathrm{R}^{2}=0,37$ \\
\hline
\end{tabular}


and urban planning factors by implementing the proposed systematic measures. Thus, the study proposes to increase the systematic spatial and urban development by an average of $30 \%$.

For the investment and environmental indicators, the integral indicator of territorial development of land use of the regions is forecasted, depending on their change, the results of which are presented in Table 2 and 3.

As a result of forecasting the integral indicator of territorial development of land use of regions based on the growth of systemic investment factor, it is necessary to increase it by $30 \%$ to ensure territorial development in all regions.
This significant growth can be ensured through the implementation of a set of long-term measures.

The results of forecasting the integral indicator of territorial development of land use in the regions based on the growth of the systemic environmental factor indicate the need to increase it by $20 \%$ to ensure the growth of the integrated indicator in all regions of Ukraine.

The results of determining the forecast values of systematic spatial, urban, investment and environmental indicators according to the established growth levels are presented in Table 4.

Table 2

The results of forecasting the integral indicator of territorial development of land use of regions based on the growth of systemic investment factor, rel. units

\begin{tabular}{|l|c|c|c|c|c|c|c|c|}
\hline \multirow{2}{*}{\multicolumn{1}{|c|}{ Regions }} & \multicolumn{6}{|c|}{ Changes in the integral indicator of territorial development } \\
& \multicolumn{1}{|c|}{ of land use of regions based on the growth of systemic investment factor on: } \\
\hline \hline Vinnytskyi & $-0,002$ & $-0,002$ & $-0,0004$ & 0,001 & 0,003 & 0,005 & 0,007 & 0,009 \\
\hline Volynskyi & $-0,004$ & $-0,004$ & $-0,0025$ & $-0,001$ & 0,001 & 0,003 & 0,005 & 0,007 \\
\hline Dnipropetrovskyi & $-0,002$ & $-0,001$ & $-0,0002$ & 0,002 & 0,004 & 0,006 & 0,007 & 0,009 \\
\hline Donetskyi & 0,001 & 0,002 & 0,0027 & 0,005 & 0,007 & 0,008 & 0,010 & 0,012 \\
\hline Zhytomyrskyi & 0,0001 & 0,001 & 0,0017 & 0,004 & 0,005 & 0,007 & 0,009 & 0,011 \\
\hline Zakarpatskyi & $-0,001$ & $-0,001$ & 0,0005 & 0,002 & 0,004 & 0,006 & 0,008 & 0,010 \\
\hline Zaporizkyi & 0,000 & 0,001 & 0,0017 & 0,004 & 0,006 & 0,007 & 0,009 & 0,011 \\
\hline Ivano-Frankivskyi & $-0,004$ & $-0,004$ & $-0,0026$ & $-0,001$ & 0,001 & 0,003 & 0,005 & 0,007 \\
\hline Kyivskyi & 0,002 & 0,002 & 0,0036 & 0,006 & 0,007 & 0,009 & 0,011 & 0,013 \\
\hline Kropyvnytskyi & $-0,00006$ & 0,000 & 0,0015 & 0,003 & 0,005 & 0,007 & 0,009 & 0,011 \\
\hline Luhanskyi & 0,003 & 0,004 & 0,0048 & 0,007 & 0,009 & 0,011 & 0,012 & 0,014 \\
\hline Lvivskyi & $-0,003$ & $-0,003$ & $-0,0014$ & 0,001 & 0,002 & 0,004 & 0,006 & 0,008 \\
\hline Mykolaivskyi & 0,00014 & 0,001 & 0,0017 & 0,004 & 0,005 & 0,007 & 0,009 & 0,011 \\
\hline Odeskyi & 0,020 & 0,021 & 0,0218 & 0,024 & 0,026 & 0,028 & 0,029 & 0,031 \\
\hline Poltavskyi & $-0,009$ & $-0,009$ & $-0,0078$ & $-0,006$ & $-0,004$ & $-0,002$ & $-0,0001$ & 0,002 \\
\hline Rivnenskyi & 0,0003 & 0,001 & 0,0019 & 0,004 & 0,006 & 0,008 & 0,010 & 0,011 \\
\hline Sumskyi & 0,014 & 0,014 & 0,0154 & 0,017 & 0,019 & 0,021 & 0,023 & 0,025 \\
\hline Ternopilskyi & 0,00003 & 0,000 & 0,0016 & 0,003 & 0,005 & 0,007 & 0,009 & 0,011 \\
\hline Kharkivskyi & $-0,004$ & $-0,003$ & $-0,0022$ & $-0,0003$ & 0,002 & 0,004 & 0,005 & 0,007 \\
\hline Khersonskyi & $-0,002$ & $-0,001$ & $-0,0001$ & 0,002 & 0,004 & 0,006 & 0,008 & 0,009 \\
\hline Khmelnytskyi & 0,0004 & 0,001 & 0,0019 & 0,004 & 0,006 & 0,008 & 0,010 & 0,012 \\
\hline Cherkaskyi & 0,001 & 0,002 & 0,0030 & 0,005 & 0,007 & 0,009 & 0,011 & 0,013 \\
\hline Chernivetskyi & $-0,001$ & $-0,001$ & 0,0006 & 0,003 & 0,004 & 0,006 & 0,008 & 0,01 \\
\hline Chernihivskyi & $-0,003$ & $-0,002$ & $-0,0013$ & 0,001 & 0,002 & 0,004 & 0,006 & 0,008 \\
\hline
\end{tabular}

* the coastal regions of Ukraine are defined in color. 
Results of forecasting the integral indicator of territorial development of land use of regions based on the growth of systemic environmental factor, rel. units

\begin{tabular}{|c|c|c|c|c|c|c|}
\hline \multirow{2}{*}{ Regions } & \multicolumn{6}{|c|}{$\begin{array}{l}\text { Changes in the integral indicator of territorial development of land use } \\
\text { of regions based on the growth of systemic environmental factor into: }\end{array}$} \\
\hline & $1 \%$ & $2 \%$ & $5 \%$ & $10 \%$ & $15 \%$ & $20 \%$ \\
\hline Vinnytskyi & $-0,002$ & $-0,001$ & $-0,0001$ & 0,002 & 0,004 & 0,006 \\
\hline Volynskyi & 0,006 & 0,007 & 0,0081 & 0,01 & 0,012 & 0,069 \\
\hline Dnipropetrovskyi & 0,002 & 0,003 & 0,004 & 0,006 & 0,008 & 0,065 \\
\hline Donetskyi & $-0,00001$ & 0,0004 & 0,0016 & 0,004 & 0,006 & 0,063 \\
\hline Zhytomyrskyi & $-0,0003$ & 0,0001 & 0,0013 & 0,003 & 0,005 & 0,062 \\
\hline Zakarpatskyi & 0,001 & 0,001 & 0,0024 & 0,004 & 0,007 & 0,063 \\
\hline Zaporizkyi & 0,004 & 0,004 & 0,0055 & 0,008 & 0,01 & 0,066 \\
\hline Ivano-Frankivskyi & 0,0003 & 0,001 & 0,0019 & 0,004 & 0,006 & 0,062 \\
\hline Kyivskyi & 0,004 & 0,004 & 0,0054 & 0,007 & 0,01 & 0,066 \\
\hline Kropyvnytskyi & $-0,0003$ & 0,0001 & 0,0013 & 0,003 & 0,005 & 0,062 \\
\hline Luhanskyi & $-0,003$ & $-0,002$ & $-0,001$ & 0,001 & 0,003 & 0,060 \\
\hline Lvivskyi & 0,002 & 0,002 & 0,0032 & 0,005 & 0,007 & 0,064 \\
\hline Mykolaivskyi & 0,00114 & 0,002 & 0,0028 & 0,005 & 0,007 & 0,064 \\
\hline Odeskyi & 0,001 & 0,001 & 0,0023 & 0,004 & 0,006 & 0,064 \\
\hline Poltavskyi & $-0,002$ & $-0,001$ & 0,0001 & 0,002 & 0,004 & 0,060 \\
\hline Rivnenskyi & 0,0001 & 0,001 & 0,0018 & 0,004 & 0,006 & 0,063 \\
\hline Sumskyi & 0,001 & 0,001 & 0,0026 & 0,005 & 0,007 & 0,064 \\
\hline Ternopilskyi & $-0,0068$ & $-0,006$ & $-0,005$ & $-0,003$ & $-0,001$ & 0,056 \\
\hline Kharkivskyi & 0,0004 & 0,001 & 0,002 & 0,0041 & 0,006 & 0,063 \\
\hline Khersonskyi & $-0,004$ & $-0,003$ & $-0,002$ & 0,000 & 0,002 & 0,059 \\
\hline Khmelnytskyi & 0,0013 & 0,002 & 0,0029 & 0,005 & 0,007 & 0,064 \\
\hline Cherkaskyi & 0,001 & 0,002 & 0,0031 & 0,005 & 0,007 & 0,064 \\
\hline Chernivetskyi & 0,002 & 0,002 & 0,0032 & 0,005 & 0,007 & 0,064 \\
\hline Chernihivskyi & $-0,002$ & $-0,001$ & 0,0001 & 0,002 & 0,004 & 0,061 \\
\hline
\end{tabular}

* the coastal regions of Ukraine are defined in color.

The results of determining the forecast values of systematic spatial, urban, investment and environmental indicators in accordance with the established growth rates, rel. units

\begin{tabular}{|l|c|c|c|c|}
\hline \multirow{2}{*}{\multicolumn{1}{|c}{ Regions }} & \multicolumn{4}{c|}{ Forecast values of systemic factors } \\
\cline { 2 - 5 } & Spatial & Urban development & Investment & Ecological \\
\hline \hline Vinnytskyi & 5,49 & 5,353 & 1,893 & 3,478 \\
\hline Volynskyi & 5,484 & 5,356 & 1,651 & 3,571 \\
\hline Dnipropetrovskyi & 5,492 & 5,352 & 1,765 & 3,482 \\
\hline Donetskyi & 5,492 & 5,35 & 1,829 & 3,383 \\
\hline Zhytomyrskyi & 5,484 & 5,359 & 1,862 & 3,432 \\
\hline
\end{tabular}


End of Table 4

\begin{tabular}{|l|c|c|c|c|}
\hline \multirow{2}{*}{\multicolumn{1}{|c|}{ Regions }} & \multicolumn{4}{|c|}{ Forecast values of systemic factors } \\
\cline { 2 - 5 } & Spatial & Urban development & Investment & Ecological \\
\hline \hline Zakarpatskyi & 5,476 & 5,351 & 1,821 & 3,464 \\
\hline Zaporizkyi & 5,492 & 5,355 & 1,728 & 3,437 \\
\hline Ivano-Frankivskyi & 5,48 & 5,356 & 1,82 & 3,538 \\
\hline Kyivskyi & 5,486 & 5,356 & 1,724 & 3,377 \\
\hline Kropyvnytskyi & 5,492 & 5,35 & 1,855 & 3,432 \\
\hline Luhanskyi & 5,49 & 5,35 & 1,934 & 3,337 \\
\hline Lvivskyi & 5,486 & 5,355 & 1,791 & 3,516 \\
\hline Mykolaivskyi & 5,492 & 5,366 & 1,794 & 3,416 \\
\hline Odeskyi & 5,442 & 5,149 & 1,832 & 2,848 \\
\hline Poltavskyi & 5,49 & 5,352 & 1,88 & 3,69 \\
\hline Rivnenskyi & 5,482 & 5,356 & 1,834 & 3,416 \\
\hline Sumskyi & 5,44 & 5,16 & 1,819 & 3,031 \\
\hline Ternopilskyi & 5,49 & 5,355 & 2,062 & 3,416 \\
\hline Kharkivskyi & 5,492 & 5,352 & 1,832 & 3,541 \\
\hline Khersonskyi & 5,49 & 5,353 & 1,937 & 3,454 \\
\hline Khmelnytskyi & 5,49 & 5,353 & 1,803 & 3,42 \\
\hline Cherkaskyi & 5,488 & 5,355 & 1,804 & 3,397 \\
\hline Chernivetskyi & 5,486 & 5,351 & 1,793 & 3,457 \\
\hline Chernihivskyi & 5,488 & 5,357 & 1,895 & 3,515 \\
\hline
\end{tabular}

* the coastal regions of Ukraine are defined in color.

According to the developed generalizing model, the systematic indicators determined the estimation of the predicted integral factor of territorial development of land use of the regions (Table 5).

The level of growth of the predictive value of the integral indicator of territorial develop- ment of land use of the regions is presented in Table 6 .

Thus, the predicted values of the integral factor of territorial development of land use in the regions and the tendency of its growth indicate the possibility of implementing the growth scenario. However, it is necessary to check

Table 5

Results of estimation of the predicted integral factor of territorial development of land use of regions, rel. units

\begin{tabular}{|l|c|}
\hline \multicolumn{1}{|c|}{ Regions } & Value \\
\hline \hline Vinnytskyi & 3,729 \\
\hline Volynskyi & 3,628 \\
\hline Dnipropetrovskyi & 3,666 \\
\hline Donetskyi & 3,672 \\
\hline Zhytomyrskyi & 3,702 \\
\hline Zakarpatskyi & 3,687 \\
\hline Zaporizkyi & 3,635 \\
\hline Ivano-Frankivskyi & 3,708 \\
\hline
\end{tabular}


End of Table 5

\begin{tabular}{|l|c|}
\hline \multicolumn{1}{|c|}{ Regions } & Value \\
\hline \hline Kyivskyi & 3,616 \\
\hline Kropyvnytskyi & 3,698 \\
\hline Luhanskyi & 3,711 \\
\hline Lvivskyi & 3,688 \\
\hline Mykolaivskyi & 3,666 \\
\hline Odeskyi & 3,477 \\
\hline Poltavskyi & 3,778 \\
\hline Rivnenskyi & 3,683 \\
\hline Sumskyi & 3,527 \\
\hline Ternopilskyi & 3,793 \\
\hline Kharkivskyi & 3,716 \\
\hline Khersonskyi & 3,745 \\
\hline Khmelnytskyi & 3,669 \\
\hline Cherkaskyi & 3,664 \\
\hline Chernivetskyi & 3,673 \\
\hline Chernihivskyi & 3,741 \\
\hline
\end{tabular}

* the coastal regions of Ukraine are defined in color.

The level of growth of the predictive value of the integral indicator of territorial development of land use in the regions, rel. units

\begin{tabular}{|l|c|c|}
\hline \multicolumn{1}{|c|}{ Regions } & $\begin{array}{c}\text { The absolute value } \\
\text { of the integral metric }\end{array}$ & $\begin{array}{c}\text { The relative value } \\
\text { of the integral index }\end{array}$ \\
\hline \hline Vinnytskyi & 1,905 & 2,045 \\
\hline Volynskyi & 1,809 & 1,994 \\
\hline Dnipropetrovskyi & 1,846 & 2,015 \\
\hline Donetskyi & 1,853 & 2,019 \\
\hline Zhytomyrskyi & 1,881 & 2,033 \\
\hline Zakarpatskyi & 1,866 & 2,025 \\
\hline Zaporizkyi & 1,818 & 2,001 \\
\hline Ivano-Frankivskyi & 1,884 & 2,033 \\
\hline Kyivskyi & 1,801 & 1,992 \\
\hline Kropyvnytskyi & 1,877 & 2,031 \\
\hline Luhanskyi & 1,891 & 2,039 \\
\hline Lvivskyi & 1,866 & 2,024 \\
\hline Mykolaivskyi & 1,847 & 2,015 \\
\hline Odeskyi & 1,677 & 1,932 \\
\hline Poltavskyi & 1,947 & 2,064 \\
\hline Rivnenskyi & 1,863 & 2,024 \\
\hline Sumskyi & 1,721 & 1,953 \\
\hline
\end{tabular}


End of Table 6

\begin{tabular}{|l|c|c|}
\hline \multicolumn{1}{|c|}{ Regions } & $\begin{array}{c}\text { The absolute value } \\
\text { of the integral metric }\end{array}$ & $\begin{array}{c}\text { The relative value } \\
\text { of the integral index }\end{array}$ \\
\hline \hline Ternopilskyi & 1,966 & 2,076 \\
\hline Kharkivskyi & 1,892 & 2,037 \\
\hline Khersonskyi & 1,920 & 2,052 \\
\hline Khmelnytskyi & 1,850 & 2,017 \\
\hline Cherkaskyi & 1,846 & 2,015 \\
\hline Chernivetskyi & 1,853 & 2,018 \\
\hline Chernihivskyi & 1,916 & 2,050 \\
\hline
\end{tabular}

* the coastal regions of Ukraine are defined in color.

another important condition - the level of influence of the system spatial, urban, investment and environmental factors. This test is performed on the basis of mathematical modeling of the influence of the predicted values of the system indicators on the predictive integral factor. Mathematical models and values of the coefficients of determination are presented in Table 7.

The study found a positive impact of systematic spatial, urban, investment, environmental indicators on the integral factor of territorial development of land use in the regions. The values of the coefficients of determination indicate an increase in the stability of the developed mathematical models.

On the basis of the predicted values of the integral factor of territorial development of land use of regions and its data, a geoinformation three-dimensional model of monitoring of the state and forecast tendencies of territorial development of land use of regions was constructed (Fig. 1).

The study determined that the territorial development, in particular, coastal regions, sub- stantially influenced the direction and the peculiarities of formation and implementation of environmental policy, its normative-legal provision. Spatial, urban, investment factors do not provide significant changes in the territorial development of coastal regions, taking into account the trends and features of land use. Therefore, it is necessary to radically change the policy to ensure the territorial development of the coastal regions of Ukraine, considering the experience of China. In particular, the form of the free economic zones, improving the efficiency of land use, the use of modern information systems spatial software, and the improved utilization of urban services, increase the level of investments on the basis of modern investment mechanisms.

Conclusions. The study carried out mathematical modeling of territorial development of regions, taking into account the trends and features of land use, carried out forecasting of changes in the system of spatial, urban, investment and environmental factors and their impact on territorial development. On the basis of this research the three-dimensional GIS model

Table 7

Mathematical models of influence of predictive values of systematic spatial, urban, investment and environmental indicators on the predictive integral factor of territorial development of land use of regions and values of determination coefficients, rel. units

\begin{tabular}{|l|c|c|}
\hline \multicolumn{1}{|c|}{ System metrics } & $\begin{array}{c}\text { A model that characterizes } \\
\text { the influence of a system indicator } \\
\text { on an integral factor }\end{array}$ & Determination factor \\
\hline \hline Spatial & $\mathrm{y}=3,486 \times \mathrm{x}-15,44$ & $\mathrm{R}^{2}=0,544$ \\
\hline Urban development & $\mathrm{y}=0,953 \times \mathrm{x}-1,409$ & $\mathrm{R}^{2}=0,602$ \\
\hline Investment & $\mathrm{y}=0,483 \times \mathrm{x}+2,793$ & $\mathrm{R}^{2}=0,32$ \\
\hline Ecological & $\mathrm{y}=0,331 \times \mathrm{x}+2,548$ & $\mathrm{R}^{2}=0,634$ \\
\hline
\end{tabular}




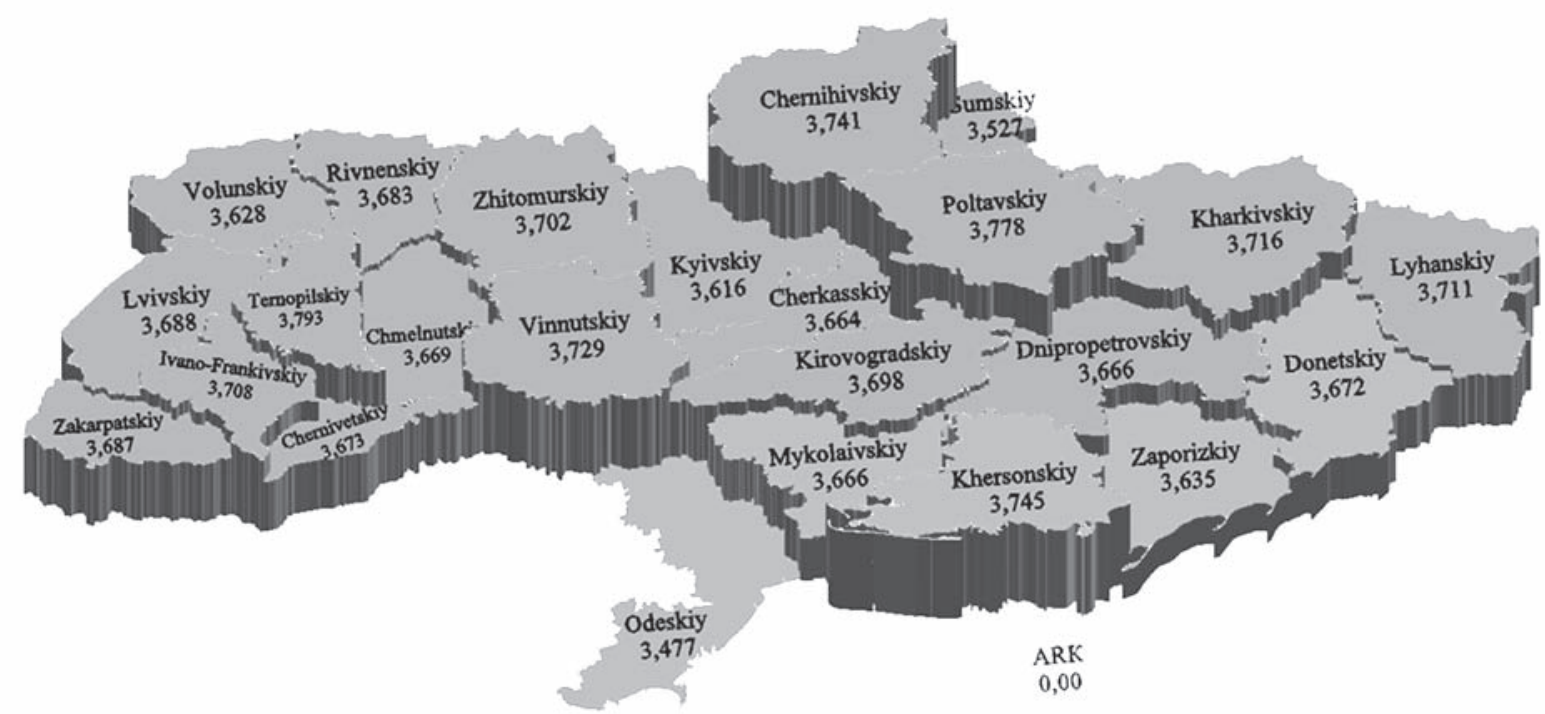

Fig. 1. Geoinformation three-dimensional model of monitoring the status and forecast tendencies of territorial development of land use of regions, rel. units

* the coastal regions of Ukraine are defined in color.

of condition monitoring and predictive trends of territorial development, land use regions, set a small level even in the forecast period.
It is proposed to use the experience of the territorial development of the coastal regions of China.

\section{СПИСОК ВИКОРИСТАНИХ ДЖЕРЕЛ}

1. Авраменко Т.П. Трансформація земельних ресурсів в аграрному секторі. Науковиий вісник Херсонського державного університету. Серія «Економічні науки.» 2015. № 14. Ч. 1. С. 107-111.

2. Бакаєв О.О., Гриценко В.І., Бажан Л.І. та ін. Економіко-математичні моделі економічного зростання: наук. вид. НАН України. МОН України. Міжнар. наук.-навч. центр інформ. технології та систем. Київ: Наукова думка, 2005. 189 с.

3. Грек М.О. Метод і моделі впливу містобудівних фракторів на використання земель міст: дис. на здобуття наукового ступеня канд. тех. наук зі спеціальності 05.24.04 - Кадастр та моніторинг земель. Харків: Харківський національний університет міського господарства імені О. М. Бекетова. 199 с.

4. Територіальниий розвиток та регіональна політика в Україні. НАН України. ДУ «Інститут регіональних досліджень імені М.І. Долішнього НАН України»; наук. ред. В.С. Кравців. Львів, 2015. $246 \mathrm{c}$.

5. Мамонов К.А. Застосування геоінформаційних систем у процесі землеустрою міст України. Комуналъне господарство міст. Серія «Технічні науки та архітектура». 2016. Вип. 130.116 с.

6. Мамонов К.А. Застосування ВЕБ геоінформаційних систем для розподілу та використання земель. Комуналъне господарство міст. Серія: «Технічні науки та архітектура». 2016. Вип. 132.144 с.

7. Свиридова Л.А. Світовий досвід державного адміністрування використання та охорони земель із врахуванням вимог екологічної безпеки. Землеустрій, кадастр і моніторинг земелъ. 2016. № 4. C. $74-83$.

8. Steven, C.B., Yu-Hung, Hong. (2003). Leasing public land: policy debates and international experiences: Lincoln Institute of Land Policy. Cambridge, Massachusetts: 303.

9. Шипулін В.Д. Система земельного адміністрування: основи сучасної теорії: навч. посіб. Харків. нац. ун-т міськ. госп-ва ім. О. М. Бекетова. Харків: ХНУМГ ім. О. М. Бекетова, 2016. 225 с.

10. Hendrik Ploeger and Jantien Stoter. (2004). Cadastral Registration of Cross-Boundary Infrastructure Objects. Proceedings of FIG Working Week, Athens, Greece. May. URL: http://www.juritecture.net (дата звернення: 14.04.2020).

\section{Authors}

Liu Chang - PhD., Associate Professor, Institute of electronics and information engineering, Guangdong Ocean University, (1, St. Haida, Zhanjiang City, Guangdong Province, PRC; e-mail: byndgjc@163.com). 
Mamonov Kostiantyn - Doctor of Economics, Professor, Professor of the Department of Land Administration and Geological Information Systems, National University of Urban Economy (St. M. Bazhanov, Kharkiv, 61002, Ukraine; e-mail: kostia.mamonov2017@gmail.com)

Лю Чан

кандидат економічних наук, доцент Інститут електроніки та інорормаційної інженерії,

Університет океану Гуандун

(КНР, пров. Гуандун, м. Чжаньцзян; e-mail: byndgjc@163.com)

К. Мамонов

доктор економічних наук, професор, профресор кафредри земельного адміністрування та геоінформаційних систем Харківський національний університет міського господарства імені О.М. Бекетова

(Україна, м. Харків; е-mail: kostia.mamonov2017@gmail.com)

\section{МАТЕМАТИЧНА МОДЕЛЬ ТЕРИТОРІАЛЬНОГО РОЗВИТКУ ПРИМОРСЬКИХ РЕГІОНІВ}

Визначено, шо у системі територіального розвитку приморсъких територій на сучасному етапі запропоновано застосовувати математичний інструментарій та моделювання, ияо створює їі інбормаційне забезпечення. Метою дослідження є визначення напрямів математичного моделювання територіального розвитку приморсъких регіонів, враховуючи особливості земельних відносин. Завданнями дослідження виступають: бормування етапів математичного моделювання територіального розвитку приморсъких регіонів, враховуючи особливості земельних відносин; побудова математичної моделі у системі територіалъного розвитку приморсъких регіонів; визначення критерїв адекватності математичної моделі у систелі територіального розвитку, враховуючи особливості земельних відносин; інтерпретація отриманих результатів. Запропоновано та реалізовано етапи математичного моделювання територіального розвитку приморсъких регіонів, враховуючи напрями та особливості використання земель і зміни системних просторових, містобудівних, інвестииійних та екологічних чинників. Визначено критерії адекватності математичних моделей територіалъного розвитку приморсъких регіонів. Здійснено прогнозування змін системних просторових, містобудівних, інвестииійних та екологічних чинників $і$ змін показника територіального розвитку, зокрема приморсъких регіонів. Побудовано геоінбормачійну тривимірну модель моніторингу стану та прогнозних тендениій територіалъного розвитку використання земель, зокрема приморсъких регіонів України. Для забезпечення територіального розвитку приморсъких регіонів запропоновано застосовувати досвід Китаю. Зокрема, бормувати вільні економічні зони, зростання ебективності використання земель, застосування сучасних інбормаційних систем просторового забезпечення, підвищення ебективності використання містобудівного забезпечення, зростання рівня інвестування на основі сучасних інвестищійних механізмів.

Ключові слова: територіалъний розвиток, приморсъкі регіони України, приморсъкі регіони Китаю, просторові, містобудівні, екологічні, інвестиційні чинники, використання земель, показник територіального розвитку, математичне моделювання, прогнозування.

\section{REFERENCES}

1. Avramenko, T.P. (2015). Trancformatsiia zemelnykh recurciv v ahrarnomu cektori [Transformation of land resources in the agrarian sector]. Naukovyy visnyk Khersonskoho derzhavnoho universytetu. 14: 107-111. [In Ukr.].

2. Bakaiev, O.O., Hrytsenko, V.I., Bazhan, L.I. et al. (2005). Ekonomiko-matematychni modeli ekonomichnoho zrostannia [Economic and mathematical models of economic growth]. Kyiv: Naukova dumka: 189. [In Ukr.].

3. Hrek, M.O. (2018). Metod i modeli vplyvu mistobudivnykh faktoriv na vykorystannia zemel mist [Method and models of influence of urban planning factors on land use of cities]. (PhD Thesis). Kharkiv: 199. [In Ukr.].

4. Kravtsiv, V.S. (Eds.) (2015). Terytorialnyy rozvytok ta rehionalna polityka v Ukraini [Territorial development and regional policy in Ukraine]. Lviv: 246. [In Ukr.].

5. Mamonov, K.A. (2016). Zastosuvannia heoinformatsiinykh system u protsesi zemleustroiu mist Ukrainy [Application of geoinformation systems in the process of land management of Ukrainian cities]. Komunalne hospodarstvo mist. 130: 116. [In Ukr.]. 
6. Mamonov, K.A. (2016). Zastosuvannia VEB heoinformatsiinykh system dlia rozpodilu ta vykorystannia zemel [Application of WEB geoinformation systems for land distribution and use]. Komunalne hospodarstvo mist. 132: 144. [In Ukr.].

7. Svyrydova, L.A. (2016). Svitovyi dosvid derzhavnoho administruvannia vykorystannia ta okhorony zemel iz vrakhuvanniam vymoh ekolohichnoi bezpeky [World experience in state administration of land use and protection with consideration of environmental safety requirements]. Zemleustriy, kadastr $i$ monitorynh zemel. 4: 74-83. [In Ukr.].

8. Steven, C. Bourassa \& Yu-Hung, Hong (Eds.) (2003). Leasing public land: policy debates and international experiences. Cambridge, Massachusetts: 303.

9. Shypulin, V.D. (2016). Systema zemelnoho administruvannia: osnovy suchasnoi teorii [The land administration system: basics of modern theory]. Kharkiv: KhNUMH im. O. M. Beketova: 225. [In Ukr.].

10. Hendrik, Ploeger \& Jantien, Stoter (2004). Cadastral Registration of Cross-Boundary Infrastructure Objects. Proceedings of FIG Working Week, Athens, Greece, May. URL: http://www.juritecture.net (date of accesse: 14.04 .2020 ).

\section{Інформація про авторів}

Лю Чан - кандидат економічних наук, доцент, Інститут електроніки та інформаційної інженерії, Університет океану Гуандун (вул. Хайда, 1, м. Чжаньцзян, провінція Гуандун, КНР, 524088; e-mail: byndgjc@163.com).

Мамонов Костянтин Анатолійович - доктор економічних наук, професор, професор кафедри земельного адміністрування та геоінформаційних систем, Харківський національний університет міського господарства імені О.М. Бекетова (вул. М. Бажанова, 17, м. Харків, 61002, Україна; e-mail: kostia.mamonov2017@gmail.com)

This arcitle is supported by the program for Guangdong Ocean University's «Innovation Strong School» in 2020 (230420023) and by the program for scientific research start-up funds of Guangdong Ocean University.

\section{HOBEHE}

6 березня 2020 року набрала чинності постанова Кабінету Міністрів України від 3 березня 2020 р. № 169 «Про затвердження Порядку використання коштів, передбачених у державному бюджеті для проведення інвентаризації земель та оновлення картографічної основи Державного земельного кадастру».

Цим документом затверджено такий Порядок використання коштів, передбачених у державному бюджеті для проведення інвентаризації земель та оновлення картографічної основи Державного земельного кадастру. Розпорядниками бюджетних коштів нижчого рівня є Держгеокадастр, який є відповідальним виконавцем бюджетної програми та його територіальні органи. 